\title{
A single-arm phase II trial of weekly nanoparticle albumin-bound paclitaxel (nab-paclitaxel) monotherapy after standard of chemotherapy for previously treated advanced non-small cell lung cancer
}

\author{
Yasuhiro Kato $^{1,2}{ }^{\mathbb{D}} \cdot$ Yusuke Okuma $^{1} \cdot$ Kageaki Watanabe $^{1} \cdot$ Makiko Yomota $^{1} \cdot$ Shoko Kawai $^{1} \cdot$ Yukio Hosomi $^{1}$. \\ Tatsuru Okamura ${ }^{1}$
}

Received: 20 March 2019 / Accepted: 12 April 2019 / Published online: 16 April 2019

(c) The Author(s) 2019

\begin{abstract}
Background Few studies have investigated the clinical efficacy of third- and later-line of chemotherapy after standard chemotherapy for previously treated advanced non-small cell lung cancer (NSCLC). We prospectively evaluated the efficacy and safety of nanoparticle albumin-bound paclitaxel (nab-paclitaxel) following standard chemotherapies for previously treated advanced NSCLC.

Methods The eligible patients having adequate organ functions with performance status $0-2$ were enrolled after completing standard chemotherapy. They received weekly nab-paclitaxel $100 \mathrm{mg} / \mathrm{m}^{2}$ intravenously on days 1,8 , and 15 every 3 weeks. The primary end point was objective response rate (ORR). Median progression-free survival (PFS), overall survival (OS), and adverse events (AEs) were evaluated as secondary end points.

Results This trial was discontinued because of late accrual. Twenty two patients were enrolled from April 2013 and February 2019. The total ORR was $22.7 \%$ [95\% CI 7.8-45.4] and disease control rate (DCR) was $81.8 \%$ [95\% CI 59.7-94.8]. Median PFS was 3.4 months [95\% CI 2.3-4.1] and median OS was 7.4 months [95\% CI 4.2-10.7]. Median follow-up interval was 6.7 months hematological AEs of Grade 3/4 included anemia (18\%), leukopenia (18\%), and neutropenia (32\%), while the most frequent nonhematological AEs were fatigue (50\%) and peripheral neuropathy (36.4\%). Severe AEs related to treatment were observed in only one patient.

Conclusion Nab-paclitaxel may be a safe and effective later-line chemotherapeutic option for previously treated advanced NSCLC after standard of chemotherapies based on other trials.
\end{abstract}

Keywords Advanced non-small cell lung cancer $\cdot$ Chemotherapy $\cdot$ Nanoparticle albumin-bound paclitaxel $\cdot$ Later line setting

Yasuhiro Kato

y-kato@nms.ac.jp

1 Department of Thoracic Oncology and Respiratory Medicine, Tokyo Metropolitan Cancer and Infectious Diseases Centre, Komagome Hospital, Honkomagome 3-18-22, Bunkyo, Tokyo 113-0021, Japan

2 Department of Pulmonary Medicine and Oncology, Graduate School of Medicine, Nippon Medical School, Tokyo, Japan

\section{Introduction}

Non-small cell lung cancer (NSCLC) is one of the most common cancers and prognosis remains poor [1]. Platinum doublet chemotherapy is currently an essential first-line therapy for NSCLC [2]. In addition, new molecular agents targeting epidermal growth factor receptor (EGFR), anaplastic lymphoma kinase (ALK), or ROS1 have dramatically improved NSCLC outcomes for patients with genetic alterations [3]. Immune checkpoint inhibitors (ICIs) are another new treatment option for NSCLC [3]. Recently, several phase III trials (Keynote 189, 407 and Impower 150) demonstrated that combination therapy with platinum doublet and 
ICI resulted in longer median overall survival (OS) for naive advanced NSCLC compared to platinum doublet therapy alone [4-6], and this combination therapy is now considered standard for NSCLC without targetable genetic alterations.

Anticancer agents like docetaxel, pemetrexed, erlotinib, and tegafur/gimeracil/oteracil (the S-1 regimen) are standard treatments for previously treated NSCLC [7-11]. Combination therapy with docetaxel and ramucirumab resulted in longer progression-free survival (PFS) in patients with platinum doublet-refractory NSCLC [12]. Recently, several phase III trials reported better efficacy of ICI treatment for platinum doublet-refractory advanced NSCLC compared to docetaxel [13-15]. Therefore, ICIs are now accepted as part of the standard regimen for advanced NSCLC.

Most advanced NSCLC patients receive several lines of treatment, but there are few prospective trials investigating the efficacy and safety of third- or later-line therapies [16]. Nanoparticle albumin-bound paclitaxel (nab-PTX) was developed as a novel cytotoxic agent with a targeted drug delivery system to improve the therapeutic index of paclitaxel [17]. As first-line treatment, carboplatin plus nabPTX combination therapy demonstrated significantly higher objective response rate (ORR), a non-significant 1-month improvement in median OS, and lower toxicity than carboplatin plus paclitaxel [18]. In addition, previous phase II trials reported good efficacy and safety of weekly nabPTX monotherapy as second line treatment for patients with platinum doublet-refractory NSCLC [19-21]. However, to our knowledge there has been no prospective trial assessing the efficacy and safety of nab-PTX as third- or later-line treatment.

Here, we present results of a single-arm phase II trial conducted at the Tokyo Metropolitan Cancer and Infectious Disease Center investigating the efficacy and safety of weekly nab-PTX monotherapy following standard chemotherapy for advanced NSCLC.

\section{Patients and methods}

\section{Eligibility criteria}

Patients consenting to later-line chemotherapy after standard therapy, with an Eastern Cooperative Oncology Group Performance Status (ECOG-PS) of 0-2, and with histologically or cytologically confirmed stage IIIB or IV NSCLC were eligible for enrollment. Patients who had received previous paclitaxel or nab-PTX treatment for NSCLC were excluded. At study onset in 2013, standard therapy was defined as chemotherapy including docetaxel and pemetrexed in patients with non-squamous cell lung cancer or docetaxel in patients with squamous cell lung cancer [8,9]. The ICI nivolumab was approved by the Ministry of Health, Labor and Welfare of Japan in December 2015, so we revised the definition of standard therapy to include ICIs in February 2016. If the tumor exhibited a genetic alteration, such as EGFR mutation or ALK rearrangement, targeted therapy using a tyrosine kinase inhibitor (TKI) was also defined as standard therapy. Other eligibility criteria included adequate cardiac, hematologic, hepatic, renal, and respiratory function [oxygen saturation in room air $\geq 90 \%$, hemoglobin content $\geq 9.0 \mathrm{~g} / \mathrm{dL}$, neutrophil count $\geq 1500 / \mathrm{mm}^{3}$, platelet count $\geq 100,000 / \mathrm{mm}^{3}$, aspartate aminotransferase (AST) and alanine aminotransferase (ALT) levels $\leq 2.5$ times the upper limit of normal, total bilirubin concentration $\leq 1.5 \mathrm{mg} / \mathrm{dL}$, and creatinine concentration $\leq 1.5 \mathrm{mg} / \mathrm{dL}]$ and life expectancy of more than 12 months. If patients had received prior radiotherapy or invasive therapy, such as chest drainage or pleurodesis, nab-PTX was not started for at least 2 weeks post-treatment. Other exclusion criteria included active concomitant malignancy without carcinoma in situ, uncontrollable central nervous system metastasis, uncontrollable pleural effusion, active infection, non-healing peptic wounds, severe complications of heart disease, interstitial pneumonia, uncontrolled hypertension, diabetes or other metabolic diseases, and drug sensitivity including to paclitaxel and albumin.

\section{Study design}

This was a phase II, single-arm, single-center, open-label study of nab-PTX in patients with relapsed NSCLC after standard chemotherapy conducted at the Tokyo Metropolitan Cancer and Infectious Disease Center, Komagome Hospital (Tokyo, Japan). The primary endpoint was ORR. Secondary endpoints included PFS, OS, and adverse events (AEs) profile. The study protocol was approved by the Institutional Review Board of Tokyo Metropolitan Cancer and Infectious Diseases Centre, Komagome Hospital (\#1212), and adhered to the tenets of the Declaration of Helsinki (World Medical Association). The study was registered with the UMIN Clinical Trials Registry (UMIN000010737). Informed consent was obtained from all participants.

\section{Treatment schedule}

All patients received nab-PTX at $100 \mathrm{mg} / \mathrm{m}^{2}$ via intravenous infusion for $30 \mathrm{~min}$ on days 1,8 , and 15 of each 3 -week cycle. Before the next treatment cycle, each patient was required to meet the following criteria: neutrophil count $\geq 1500 / \mathrm{mm}^{3}$, platelet count $\geq 75,000 / \mathrm{mm}^{3}$, hemoglobin content $\geq 9.0 \mathrm{~g} / \mathrm{dL}$, AST and ALT levels $\leq 2.5$ times the upper limit of normal, total bilirubin concentration $\leq 2.0 \mathrm{mg} /$ $\mathrm{dL}$, creatinine concentration $\leq 2.0 \mathrm{mg} / \mathrm{dL}$, and only tolerable nonhematologic AEs. On days 8 or 15 of each cycle, patients were also required to meet the following criteria: 
Table 1 Patient's characteristics

\begin{tabular}{|c|c|}
\hline Total number & $n=22$ \\
\hline \multicolumn{2}{|l|}{ Age } \\
\hline Median & 65 \\
\hline Range & $(30-79)$ \\
\hline$\geq 70$ years & $6(27.3 \%)$ \\
\hline$<70$ years & $16(72.7 \%)$ \\
\hline \multicolumn{2}{|l|}{ Gender } \\
\hline Male & $16(72.7 \%)$ \\
\hline Female & $6(27.3 \%)$ \\
\hline \multicolumn{2}{|l|}{ ECOG PS } \\
\hline 0 & $0(0.0 \%)$ \\
\hline 1 & $11(50.0 \%)$ \\
\hline 2 & $11(50.0 \%)$ \\
\hline \multicolumn{2}{|l|}{ Histology } \\
\hline Adenocarcinoma & $13(59.1 \%)$ \\
\hline Squamous cell carcinoma & $9(41.0 \%)$ \\
\hline \multicolumn{2}{|l|}{ A number of prior therapies } \\
\hline Median (range) & $4(3-7)$ \\
\hline$\geq 4$ th line & $17(77.3 \%)$ \\
\hline$<4$ th line & $5(22.7 \%)$ \\
\hline \multicolumn{2}{|l|}{ Smoking history } \\
\hline Current or former smoker & $20(90.9 \%)$ \\
\hline Never smoker & $2(9.1 \%)$ \\
\hline \multicolumn{2}{|l|}{ EGFR mutation } \\
\hline Wild type & $13(59.1 \%)$ \\
\hline Mutant & $1(4.5 \%)$ \\
\hline Unknown & $8(36.4 \%)$ \\
\hline \multicolumn{2}{|l|}{ ALK rearrangement } \\
\hline Wild type & $13(59.1 \%)$ \\
\hline Positive & $1(4.5 \%)$ \\
\hline Unknown & $8(36.4 \%)$ \\
\hline \multicolumn{2}{|l|}{ Prior EGFR/ALK-TKIs } \\
\hline Yes & $5(22.7 \%)$ \\
\hline No & $17(77.3 \%)$ \\
\hline \multicolumn{2}{|l|}{ Prior docetaxel } \\
\hline Yes & $22(100.0 \%)$ \\
\hline No & $0(0.0 \%)$ \\
\hline \multicolumn{2}{|l|}{ Prior ICI } \\
\hline Yes & $6(27.3 \%)$ \\
\hline No & $16(72.7 \%)$ \\
\hline
\end{tabular}

ECOG PS Eastern Cooperative Oncology Group Performance Status, $E G F R$ epidermal growth factor receptor, $A L K$ anaplastic lymphoma kinase, TKI tyrosine kinase inhibitor, ICI immune checkpoint inhibitor

neutrophil count $\geq 1000 / \mathrm{mm}^{3}$, platelet count $\geq 50,000 / \mathrm{mm}^{3}$, peripheral neuropathy $<$ grade 3 , and ECOG PS $\leq 2$. Dose reductions of $25 \mathrm{mg} / \mathrm{m}^{2}$ to a minimum dose of $50 \mathrm{mg} / \mathrm{m}^{2}$ were allowed for grade 4 neutropenia lasting longer than
Table 2 Response to weekly nab-PTX monotherapy after standard therapies

\begin{tabular}{llr}
\hline Response & Number of patients & $\%$ \\
\hline CR & 0 & 0.0 \\
PR & 5 & 22.7 \\
SD & 13 & 59.1 \\
PD & 3 & 13.6 \\
NE & 1 & 4.5 \\
ORR & $22.7[95 \%$ CI 7.8-45.4] \\
DCR & $81.8[95 \%$ CI 59.7-94.8] \\
\hline
\end{tabular}

$C R$ complete response, $P R$ partial response, $S D$ stable disease, $P D$ progressive disease, $N E$ not evaluable, $O R R$ objective response rate, $D C R$ disease control rate

7 days, thrombocytopenia grade 3 or 4 , or any nonhematologic toxicity including peripheral neuropathy of grade 3 or 4 . Any patient who required a third dose reduction was withdrawn from the study. In addition, a patient was withdrawn if the next cycle was not started 3 weeks from the end of the previous treatment cycle. Treatment cycles continued unless there was progressive disease or intolerable AEs, or if the patient refuses to continue treatment.

After protocol treatment completion, the next chemotherapy was not started until disease progression. However, any treatment (including ICIs) was allowed after disease progression.

\section{Treatment assessment}

Baseline disease and response to therapy were assessed using the Response Evaluation Criteria in Solid Tumors version 1.1 (RECIST ver.1.1). Chest X-ray was conducted after every treatment cycle, and chest and abdominal computed tomographic scan (CT scan) was conducted routinely every 6 weeks. Whole-brain magnetic resonance imaging and isotope bone scan or positron emission tomography with 2-deoxy-2-[fluorine-18] fluoro-D-glucose integrated with computed tomography $\left({ }^{18} \mathrm{~F}\right.$-FDG PET/CT) were conducted for disease evaluation. Patients showing a complete response (CR) or a partial response (PR) received imaging examination as confirmatory evaluation after an interval of at least 4 weeks post-treatment. A patient was classified with stable disease (SD) if the response was confirmed and maintained for 6 weeks or longer after the start of the protocol treatment. Progress-free survival was defined as the time from study entry to disease progression or death by any cause, and OS as the time from study entry to death by any cause.

Evaluations of participants at baseline and during or following each cycle included physical examination, vital signs, ECOG-PS, and complete hematology and biochemistry profiles. After the first cycle, all factors were evaluated 
Fig. 1 Response to nab-PTX presented as waterfall plot of greatest percentage change in target lesion size from baseline

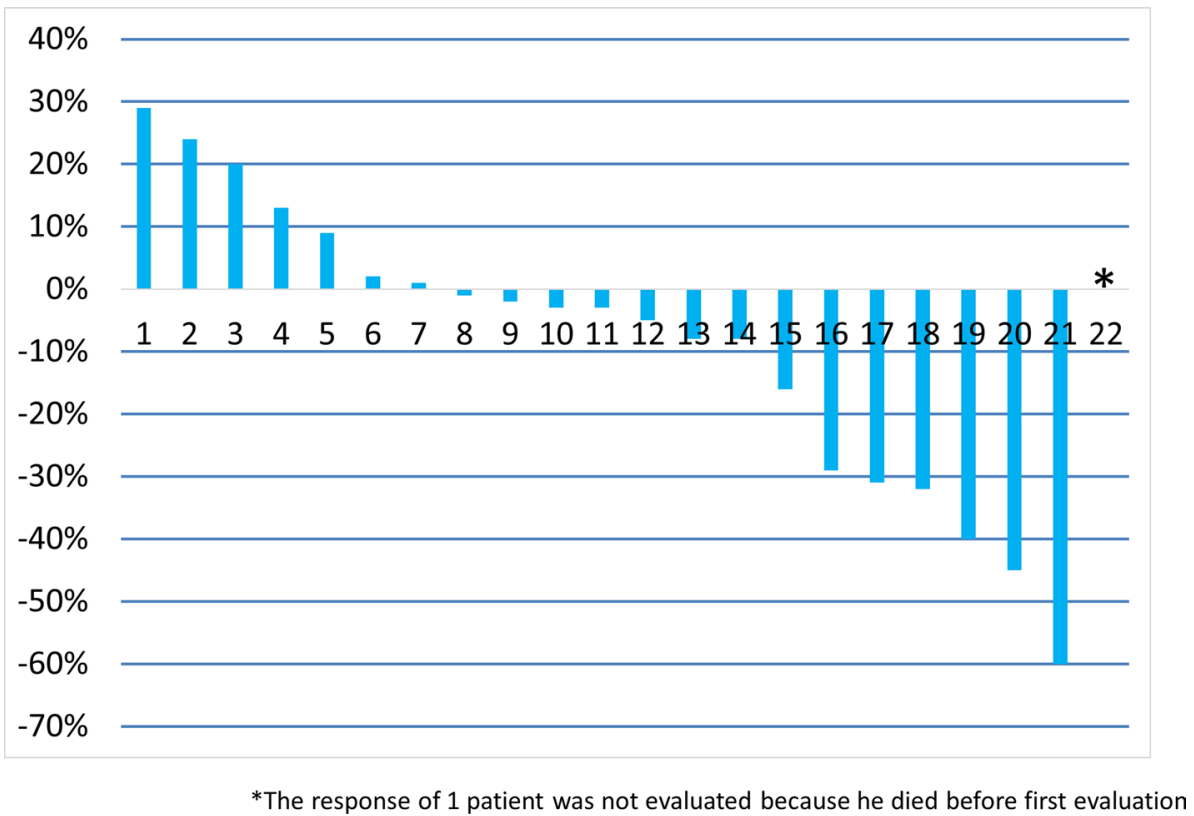

every week. AEs were categorized and graded during each cycle according to the National Cancer Institute Common Terminology Criteria for Adverse Events (CTCAE) version 4.0.

\section{Statistical analysis}

Based on a previous report, we estimated the expected ORR as $15 \%$ and the lower limit of interest as $5 \%$. As this research was designed to have a statistical power of $80 \%$ and type I error of 0.05 , we calculated that 52 patients were required and planned enrolling 55 patients over 60 months with follow-up intervals of 12 months.

Median PFS and median OS were assessed using the Kaplan-Meier method and log-rank test. For median disease control rate (DCR) and ORR, 90\% and 95\% CIs were calculated using Fisher's exact test. All statistical analyses were performed using EZR (Saitama Medical Centre, Jichi Medical University, Saitama, Japan), a graphical user interface for R (a modified R commander designed for biostatistics).

\section{Results}

\section{Patient characteristics}

The median follow-up interval was 7.1 months. Table 1 presents patient baseline characteristics. Although we expected 55 patients were enrolled in this trial, only 22/55 (40\%) patients were treated that met enrollment criteria between April 2013 and March 2018 for late accrual. Median age of the patients was 65 years (range 30-79 years) and six patients were over 70 years old. Men accounted for the majority $(16,72.7 \%)$ and 11 patients $(50.0 \%)$ had a performance status of 2 (poor). Thirteen patients $(59.1 \%)$ had adenocarcinoma and nine $(40.9 \%)$ had squamous cell carcinoma. Seventeen patients $(77.3 \%)$ had received 3 or more prior treatments. Only two patients $(9.1 \%)$ were never smokers and only one patient (4.5\%) harbored an EGFR mutation or ALK rearrangement. All patients had received chemotherapy including docetaxel and six patients (27.3\%) had received ICIs as previous therapy. Only one patient had not received prior chemotherapy using a platinum-containing regimen (due to advanced age).

\section{Treatment delivery}

The median number of chemotherapy cycles per patient was 4 (range $1-8$ cycles) (Table 1 ). The median dose intensity of nab-PTX was $62.3 \mathrm{mg} / \mathrm{m}^{2} /$ week. Eleven patients $(50 \%)$ experienced dose delay, for which the most common reason was neutropenia $(5 / 11,45.5 \%)$. However, no patients required dose reduction.

\section{Treatment efficacy}

Table 2 summarizes the treatment efficacy. Five patients achieved PR and 13 patients (59.1\%) SD, while only three patients $(18.2 \%)$ demonstrated progressive disease (PD). The total ORR was $22.7 \%$ [95\% CI 7.8-45.4] and disease control rate (DCR) was $81.8 \%$ [95\% CI 59.7-94.8]. Tumor response is presented in Fig. 1 as a waterfall plot. The response of one patient was not evaluated because he died before the first 

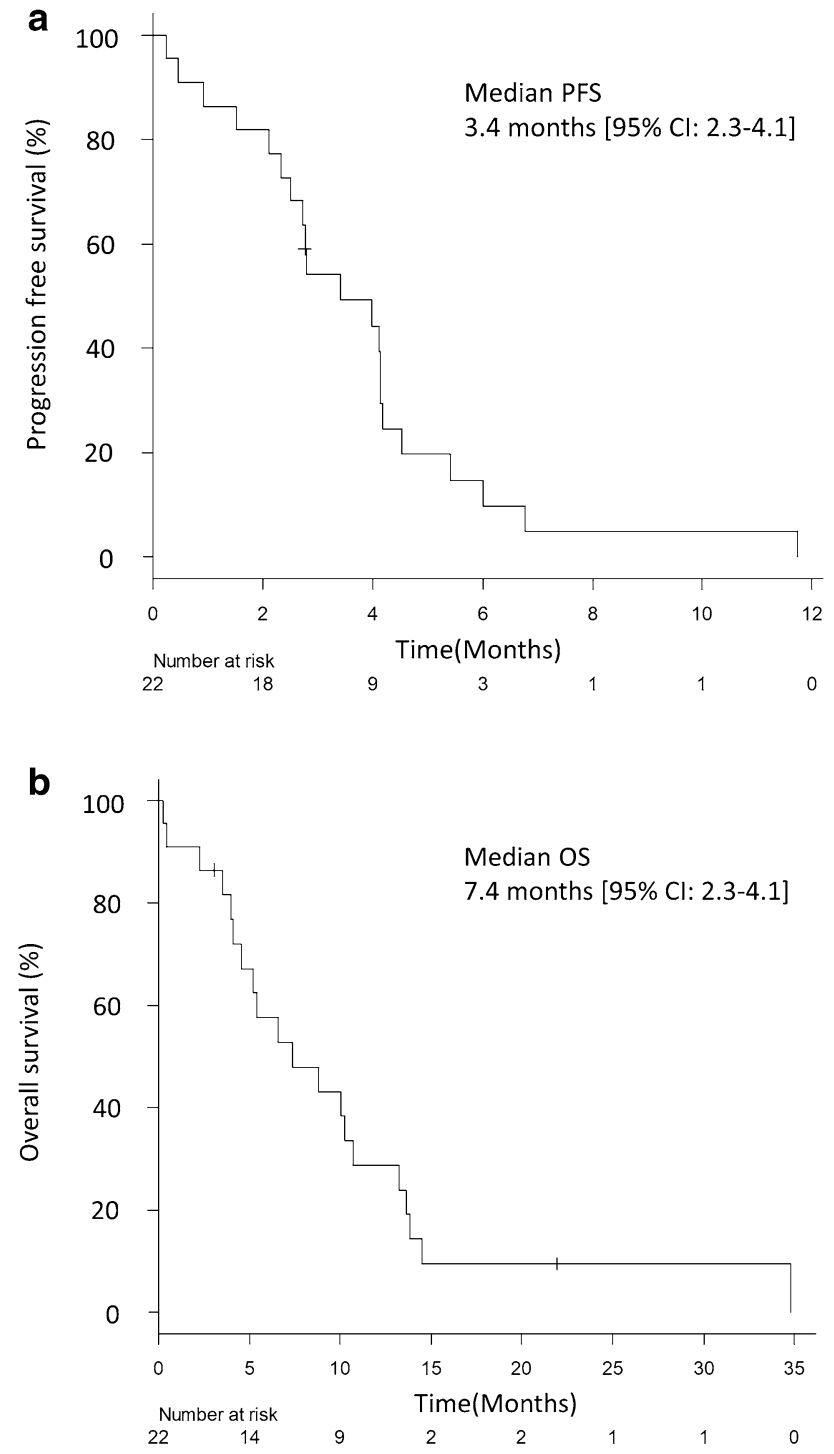

Fig. 2 Kaplan-Meier curves for PFS (a) and OS (b) of all patients enrolled in this trial evaluation. Median PFS was 3.4 months [95\% CI 2.3-4.1] (Fig. 2a) and median OS was 7.4 months [95\% CI 4.2 - 10.7] (Fig. 2b).

\section{Safety}

Profiles of major AEs are summarized in Table 3. Anemia was the most frequent $\mathrm{AE}(91 \%)$, including $18 \%$ with grade $3 / 4$ anemia (18\%). Other common hematological EAs were leukopenia (18\%) and neutropenia (32\%). Fatigue (50\%) and peripheral neuropathy $(36.4 \%)$ were the most frequent nonhematologic AEs. Although most AEs were generally mild and reversible, three patients (13.6\%) experienced severe AEs (SAEs), including one case of severe thrombocytopenia requiring blood transfusion, one case requiring hospitalization for treatment of pneumonia unrelated to protocol treatment, and one death from cerebral stroke unrelated to protocol treatment. Febrile neutropenia and interstitial lung disease were not observed in this study.

\section{Discussion}

In this trial, we present the results of a phase II trial of weekly nab-PTX monotherapy after standard chemotherapy for advanced NSCLC. Previous prospective trials concluded that weekly nab-PTX monotherapy demonstrated a useful option for platinum-refractory NSCLC (as indicated by ORRs of $16.1-31.7 \%$, DCRs of $65.9-71.9 \%$, median PFS values of 3.9-4.9 months, and median OS values of 6.8-15.7 months) [19-21]. Tanaka et al. reported an ORR of $19.3 \%$, DCR of $74.1 \%$, median PFS of 4.5 months, and median OS of 15.7 months in a single-arm phase II study of weekly nab-PTX monotherapy for patients with chemorefractory NSCLC, including patients receiving third- or later-line treatment (32\% of patients) [22]. Based on these
Table 3 Toxicities of weekly nab-PTX monotherapy treatment $(N=22)$

\begin{tabular}{lcccccc}
\hline Toxicities & Any grade & $\%$ & Grade 3 & $\%$ & Grade 4 & $\%$ \\
\hline Hematological & 20 & 91 & 2 & 9 & 2 & 9 \\
Anemia & 3 & 14 & 0 & 0 & 1 & 5 \\
Thrombocytopenia & 16 & 73 & 4 & 18 & 0 & 0 \\
Leukopenia & 15 & 68 & 7 & 32 & 0 & 0 \\
Neutropenia & & & & & 0 & 0 \\
Febrile neutropenia & 2 & & & & & \\
Non-hematological & 11 & 50 & 5 & 23 & 0 & 0 \\
Nausea & 6 & 27 & 0 & 0 & 0 & 0 \\
Fatigue & 8 & 36 & 2 & 9 & 0 & 0 \\
Anorexia & 4 & 18 & 0 & 0 & 0 & 0 \\
Peripheral neuropathy & 0 & 0 & 0 & 0 & 0 & 0 \\
ALT/AST elevation & 0 & 0 & 0 & 0 & 0 & 0 \\
Rash & & & & 0 & \\
Interstitial lung disease & & & & & \\
\hline
\end{tabular}


trials, a phase III randomized clinical trial comparing nab-PTX to docetaxel in patients with platinum doubletrefractory advanced NSCLC is currently ongoing in Japan (UMIN00017487) [23]. However, there has been no prospective trial of weekly nab-PTX for advanced NSCLC exclusively as third- or later-line therapy (i.e., excluding weekly nab-PTX as first- or second-line treatment), although two retrospective studies have examined the efficacy of weekly nab-PTX monotherapy as later-line treatment for advanced NSCLC [24, 25]. Moreover, there is little data on the efficacy and safety of third- or later-line chemotherapy for advanced NSCLC. Harada et al. reported an ORR of 9.8\%, median PFS of 3.0 months, and DCR of $61.0 \%$ for a single-arm phase II trial of amrubicin monotherapy as thirdor fourth-line treatment [26]. On the other hand, a phase II trial of erlotinib vs. S-1 as a third- or fourth-line therapy in patients with advanced NSCLC reported an ORR of $16.7 \%$, DCR of $66.7 \%$, and PFS of 3.3 months for S-1 [27], while a retrospective study reported S-1 ORR and DCR values of $17.0 \%$ and $34.4 \%$, respectively, as third-line treatment and $11.3 \%$ and $24.5 \%$, respectively, as fourth-line treatment [16].

Weekly nab-PTX monotherapy demonstrated good safety and efficacy after standard therapy for advanced NSCLC despite use as later-line treatment and despite half of the patients having poor performance status (PS of 2), suggesting that nab-PTX may be effective at any time for advanced NSCLC. Moreover, ICI was one of the key drugs for firstline treatment of advanced NSCLC, so nab-PTX appears to be a useful treatment after ICI for advanced NSCLC patients. However, only six ICI-treated patients were included, so further studies assessing efficacy of chemotherapy after ICI treatment for advanced NSCLC are required.

The main AEs encountered in this trial were anemia, leucopenia, neutropenia, and peripheral neuropathy, while only three patients experienced severe AEs. Moreover, despite the inclusion of PS 2 patients, we found that efficacy and toxicity were equivalent to previous reports on weekly nab-PTX monotherapy. Thus, the AEs associated with weekly nab-PTX for advanced NSCLC are generally acceptable and manageable.

Weekly nab-PTX yielded a high responses rate despite inclusion of docetaxel as standard therapy for all patients. Cross-resistance to taxanes has been reported in preclinical studies and studies of breast cancer [28, 29]. However, analysis of TAX 317, TAX 320, and other trials revealed that prior paclitaxel treatment did not affect docetaxel efficacy [30]. On the contrary, few studies have examined the influence of prior docetaxel on nab-PTX treatment response. Our study suggests that such cross-resistance to taxanes is minimal.

This manuscript has several limitations. The key limitation is the smaller-than-expected number of patients meeting enrollment criteria within the study period. For this reason, the primary end point was obviously underpowered. Further, the long enrollment period may have affected the results given changes in early line regimens over time. Nonetheless, this is the first trial suggesting that nab-PTX is effective and safe as even third- or later-line treatment for advanced NSCLC following standard chemotherapies (including docetaxel). The clinical utility and safety of nab-PTX as third- or later-line treatment for advanced NSCLC may be shown in the current trial with the view of the possibility of cross-resistance for docetaxel, therefore, no more further larger-scale multicenter trials will be required to verify the effectiveness.

\section{Conclusion}

Weekly nab-PTX monotherapy demonstrates good efficacy and only mild toxicity as later-line treatment after standard treatment for advanced NSCLC.

Acknowledgements The authors thank Dr. Kan Kato (Tokyo Kensei Hospital), Dr. Shingo Miyamoto (Japan Red Cross Medical Center), and Dr. Aya Yamamoto (Tokyo Metropolitan Cancer and Infectious Diseases Center, Komagome Hospital) for management and recommending the present clinical trial as the Data and Safety Monitoring Committee. The authors would also like to thank Makoto Saito (the Senior Biostatistician in Tokyo Metropolitan Cancer and Infectious diseases Center, Komagome Hospital) for statistical advice. This study was not funded by any organization. The authors would like to thank Enago (https://www.enago.jp) for the English language review.

\section{Compliance with ethical standards}

Conflict of interest $\mathrm{YH}$ and $\mathrm{YO}$ have received honoraria from TAIHO PHARMACEUTICAL. The other authors declare no conflicts of interest associated with this manuscript.

\section{Clinical trial registration UMIN-CTR identifier: UMIN000010737.}

Informed consent Informed consent was obtained from all individual participants included in the study.

Ethical approval All procedures performed in studies involving human participants were in accordance with the ethical standards of the institutional and/or national research committee and with the 1964 Helsinki declaration and its later amendments or comparable ethical standards.

Open Access This article is distributed under the terms of the Creative Commons Attribution 4.0 International License (http://creativeco mmons.org/licenses/by/4.0/), which permits unrestricted use, distribution, and reproduction in any medium, provided you give appropriate credit to the original author(s) and the source, provide a link to the Creative Commons license, and indicate if changes were made.

\section{References}

1. Siegel R, Ma J, Zou Z, Jemal A (2014) Cancer statistics, 2014. CA Cancer J Clin 64(1):9-29. https://doi.org/10.3322/caac.21208

2. Group N-sCLCC (1995) Chemotherapy in non-small cell lung cancer: a meta-analysis using updated data on individual patients 
from 52 randomised clinical trials. Non-small Cell Lung Cancer Collaborative Group. BMJ 311(7010):899-909

3. Hirsch FR, Scagliotti GV, Mulshine JL, Kwon R, Curran WJ Jr, Wu YL, Paz-Ares L (2017) Lung cancer: current therapies and new targeted treatments. Lancet 389(10066):299-311. https://doi. org/10.1016/S0140-6736(16)30958-8

4. Socinski MA, Jotte RM, Cappuzzo F, Orlandi F, Stroyakovskiy D, Nogami N, Rodriguez-Abreu D, Moro-Sibilot D, Thomas CA, Barlesi F, Finley G, Kelsch C, Lee A, Coleman S, Deng Y, Shen Y, Kowanetz M, Lopez-Chavez A, Sandler A, Reck M (2018) Atezolizumab for first-line treatment of metastatic nonsquamous NSCLC. N Engl J Med 378(24):2288-2301. https://doi. org/10.1056/NEJMoa1716948

5. Paz-Ares L, Luft A, Vicente D, Tafreshi A, Gumus M, Mazieres J, Hermes B, Cay Senler F, Csoszi T, Fulop A, Rodriguez-Cid J, Wilson J, Sugawara S, Kato T, Lee KH, Cheng Y, Novello S, Halmos B, Li X, Lubiniecki GM, Piperdi B, Kowalski DM (2018) Pembrolizumab plus chemotherapy for squamous nonsmall-cell lung cancer. N Engl J Med 379(21):2040-2051. https ://doi.org/10.1056/NEJMoa1810865

6. Gandhi L, Rodriguez-Abreu D, Gadgeel S, Esteban E, Felip E, De Angelis F, Domine M, Clingan P, Hochmair MJ, Powell SF, Cheng SY, Bischoff HG, Peled N, Grossi F, Jennens RR, Reck M, Hui R, Garon EB, Boyer M, Rubio-Viqueira B, Novello S, Kurata T, Gray JE, Vida J, Wei Z, Yang J, Raftopoulos H, Pietanza MC, Garassino MC (2018) Pembrolizumab plus chemotherapy in metastatic non-small-cell lung cancer. N Engl J Med 378(22):20782092. https://doi.org/10.1056/NEJMoa1801005

7. Fossella FV, DeVore R, Kerr RN, Crawford J, Natale RR, Dunphy F, Kalman L, Miller V, Lee JS, Moore M, Gandara D, Karp D, Vokes E, Kris M, Kim Y, Gamza F, Hammershaimb L (2000) Randomized phase III trial of docetaxel versus vinorelbine or ifosfamide in patients with advanced non-small-cell lung cancer previously treated with platinum-containing chemotherapy regimens. The TAX 320 Non-Small Cell Lung Cancer Study Group. J Clin Oncol 18(12):2354-2362. https://doi.org/10.1200/ jco.2000.18.12.2354

8. Shepherd FA, Dancey J, Ramlau R, Mattson K, Gralla R, O'Rourke M, Levitan N, Gressot L, Vincent M, Burkes R, Coughlin S, Kim Y, Berille J (2000) Prospective randomized trial of docetaxel versus best supportive care in patients with non-smallcell lung cancer previously treated with platinum-based chemotherapy. J Clin Oncol 18(10):2095-2103. https://doi.org/10.1200/ jco.2000.18.10.2095

9. Hanna N, Shepherd FA, Fossella FV, Pereira JR, De Marinis F, von Pawel J, Gatzemeier U, Tsao TC, Pless M, Muller T, Lim HL, Desch C, Szondy K, Gervais R, Shaharyar Manegold C, Paul S, Paoletti P, Einhorn L, Bunn PA Jr (2004) Randomized phase III trial of pemetrexed versus docetaxel in patients with non-smallcell lung cancer previously treated with chemotherapy. J Clin Oncol 22(9):1589-1597. https://doi.org/10.1200/jco.2004.08.163

10. Kubota K, Sakai H, Katakami N, Nishio M, Inoue A, Okamoto $\mathrm{H}$, Isobe H, Kunitoh H, Takiguchi Y, Kobayashi K, Nakamura Y, Ohmatsu H, Sugawara S, Minato K, Fukuda M, Yokoyama A, Takeuchi M, Michimae H, Gemma A, Kudoh S, Tokyo Cooperative Oncology G (2015) A randomized phase III trial of oral S-1 plus cisplatin versus docetaxel plus cisplatin in Japanese patients with advanced non-small-cell lung cancer: TCOG0701 CATS trial. Ann Oncol 26(7):1401-1408. https://doi.org/10.1093/annon c/mdv190

11. Shepherd FA, Rodrigues Pereira J, Ciuleanu T, Tan EH, Hirsh V, Thongprasert S, Campos D, Maoleekoonpiroj S, Smylie M, Martins R, van Kooten M, Dediu M, Findlay B, Tu D, Johnston D, Bezjak A, Clark G, Santabarbara P, Seymour L (2005) Erlotinib in previously treated non-small-cell lung cancer. N Engl J Med 353(2):123-132. https://doi.org/10.1056/NEJMoa050753
12. Garon EB, Ciuleanu TE, Arrieta O, Prabhash K, Syrigos KN, Goksel T, Park K, Gorbunova V, Kowalyszyn RD, Pikiel J, Czyzewicz G, Orlov SV, Lewanski CR, Thomas M, Bidoli P, Dakhil S, Gans S, Kim JH, Grigorescu A, Karaseva N, Reck M, Cappuzzo F, Alexandris E, Sashegyi A, Yurasov S, Perol M (2014) Ramucirumab plus docetaxel versus placebo plus docetaxel for secondline treatment of stage IV non-small-cell lung cancer after disease progression on platinum-based therapy (REVEL): a multicentre, double-blind, randomised phase 3 trial. Lancet 384(9944):665673. https://doi.org/10.1016/s0140-6736(14)60845-x

13. Herbst RS, Baas P, Kim DW, Felip E, Perez-Gracia JL, Han JY, Molina J, Kim JH, Arvis CD, Ahn MJ, Majem M, Fidler MJ, de Castro G Jr, Garrido M, Lubiniecki GM, Shentu Y, Im E, DolledFilhart M, Garon EB (2016) Pembrolizumab versus docetaxel for previously treated, PD-L1-positive, advanced non-small-cell lung cancer (KEYNOTE-010): a randomised controlled trial. Lancet 387(10027):1540-1550. https://doi.org/10.1016/s0140 $-6736(15) 01281-7$

14. Horn L, Spigel DR, Vokes EE, Holgado E, Ready N, Steins M, Poddubskaya E, Borghaei H, Felip E, Paz-Ares L, Pluzanski A, Reckamp KL, Burgio MA, Kohlhaeufl M, Waterhouse D, Barlesi F, Antonia S, Arrieta O, Fayette J, Crino L, Rizvi N, Reck M, Hellmann MD, Geese WJ, Li A, Blackwood-Chirchir A, Healey D, Brahmer J, Eberhardt WEE (2017) Nivolumab versus docetaxel in previously treated patients with advanced nonsmall-cell lung cancer: two-year outcomes from two randomized, open-label, phase III trials (CheckMate 017 and CheckMate 057). J Clin Oncol 35(35):3924-3933. https://doi.org/10.1200/ jco.2017.74.3062

15. Rittmeyer A, Barlesi F, Waterkamp D, Park K, Ciardiello F, von Pawel J, Gadgeel SM, Hida T, Kowalski DM, Dols MC, Cortinovis DL, Leach J, Polikoff J, Barrios C, Kabbinavar F, Frontera OA, De Marinis F, Turna H, Lee JS, Ballinger M, Kowanetz M, He P, Chen DS, Sandler A, Gandara DR (2017) Atezolizumab versus docetaxel in patients with previously treated non-smallcell lung cancer (OAK): a phase 3, open-label, multicentre randomised controlled trial. Lancet 389(10066):255-265. https://doi. org/10.1016/s0140-6736(16)32517-x

16. Asahina H, Sekine I, Horinouchi H, Nokihara H, Yamamoto N, Kubota K, Tamura T (2012) Retrospective analysis of third-line and fourth-line chemotherapy for advanced non-small-cell lung cancer. Clin Lung Cancer 13(1):39-43. https://doi.org/10.1016/j. cllc.2011.06.010 (10.1016/j.cllc.2011.06.008)

17. Desai N, Trieu V, Yao Z, Louie L, Ci S, Yang A, Tao C, De T, Beals B, Dykes D, Noker P, Yao R, Labao E, Hawkins M, Soon-Shiong P (2006) Increased antitumor activity, intratumor paclitaxel concentrations, and endothelial cell transport of cremophor-free, albumin-bound paclitaxel, ABI-007, compared with cremophor-based paclitaxel. Clin Cancer Res 12(4):1317-1324. https://doi.org/10.1158/1078-0432.Ccr-05-1634

18. Socinski MA, Okamoto I, Hon JK, Hirsh V, Dakhil SR, Page RD, Orsini J, Yamamoto N, Zhang H, Renschler MF (2013) Safety and efficacy analysis by histology of weekly nab-paclitaxel in combination with carboplatin as first-line therapy in patients with advanced non-small-cell lung cancer. Ann Oncol 24(9):23902396. https://doi.org/10.1093/annonc/mdt235

19. Sakata S, Saeki S, Okamoto I, Otsubo K, Komiya K, Morinaga R, Yoneshima Y, Koga Y, Enokizu A, Kishi H, Hirosako S, Yamaguchi E, Aragane N, Fujii S, Harada T, Iwama E, Semba H, Nakanishi Y, Kohrogi H (2016) Phase II trial of weekly nab-paclitaxel for previously treated advanced non-small cell lung cancer: Kumamoto thoracic oncology study group (KTOSG) trial 1301. Lung Cancer 99:41-45. https://doi.org/10.1016/j.lungcan.2016.06.009

20. Anzai M, Morikawa M, Okuno T, Umeda Y, Demura Y, Sonoda T, Yamaguchi M, Kanno K, Shiozaki K, Ameshima S, Akai M, Ishizuka T (2017) Efficacy and safety of nanoparticle albumin-bound 
paclitaxel monotherapy as second-line therapy of cytotoxic anticancer drugs in patients with advanced non-small cell lung cancer. Medicine 96(51):e9320. https://doi.org/10.1097/md.0000000000 009320

21. Liu Z, Wei Z, Hu Y, Gao F, Hao L, Fang P, Sun S, Li J, Jiao S (2015) A phase II open-label clinical study of comparing nabpaclitaxel with pemetrexed as second-line chemotherapy for patients with stage IIIB/IV non-small-cell lung cancer. Med Oncol (Northwood, London, England) 32(8):216. https://doi. org/10.1007/s12032-015-0660-5

22. Tanaka H, Taima K, Morimoto T, Tanaka Y, Itoga M, Nakamura K, Hayashi A, Kumagai M, Yasugahira H, Mikuniya M, Okudera K, Takanashi S, Tasaka S (2017) A single-arm phase II study of nab-paclitaxel for patients with chemorefractory non-small cell lung cancer. BMC Cancer 17(1):683. https://doi.org/10.1186/ s12885-017-3684-8

23. Yoneshima Y, Morita S, Ando M, Miura S, Yoshioka H, Abe T, Kato T, Kondo M, Hosomi Y, Hotta K, Yamamoto N, Kishimoto J, Nakanishi Y, Okamoto I (2017) Treatment rationale and design for J-AXEL: a randomized phase 3 study comparing nab-paclitaxel with docetaxel in patients with previously treated advanced nonSmall-cell lung cancer. Clin Lung Cancer 18(1):100-103. https:// doi.org/10.1016/j.cllc.2016.08.003

24. Duan J, Hao Y, Wan R, Yu S, Bai H, An T, Zhao J, Wang Z, Zhuo M, Wang J (2017) Efficacy and safety of weekly intravenous nanoparticle albumin-bound paclitaxel for non-small cell lung cancer patients who have failed at least two prior systemic treatments. Thorac Cancer 8(3):138-146. https://doi. org/10.1111/1759-7714.12413

25. Xing P, Zhu Y, Shan L, Chen S, Hao X, Li J (2017) The role of weekly nanoparticle albumin bound paclitaxel monotherapy as second line or later treatment for advanced NSCLC in China. Oncotarget 8(50):87442-87454. https://doi.org/10.18632/oncot arget. 21103

26. Harada T, Oizumi S, Ito K, Takamura K, Kikuchi E, Kuda T, Sugawara S, Suzuki A, Maemondo M, Fujita Y, Kinoshita I, Inoue
A, Hommura F, Katsuura Y, Dosaka-Akita H, Isobe H, Nishimura M (2013) A phase II study of amrubicin as a third-line or fourthline chemotherapy for patients with non-small cell lung cancer: Hokkaido Lung Cancer Clinical Study Group Trial (HOT) 0901. Oncologist 18(4):439-445. https://doi.org/10.1634/theoncolog ist.2012-0308

27. Ikezawa Y, Asahina H, Oizumi S, Watanabe M, Takamura K, Kawai Y, Yamada N, Harada T, Kinoshita I, Fujita Y, Miyauchi E, Ogi T, Amano T, Furuta M, Sakakibara-Konishi J, Nishihara H, Dosaka-Akita H, Isobe H, Nishimura M (2017) A randomized phase II trial of erlotinib vs. S-1 as a third- or fourth-line therapy for patients with wild-type EGFR non-small cell lung cancer (HOT1002). Cancer Chemother Pharmacol 80(5):955-963. https ://doi.org/10.1007/s00280-017-3432-4

28. Nyman DW, Campbell KJ, Hersh E, Long K, Richardson K, Trieu V, Desai N, Hawkins MJ, Von Hoff DD (2005) Phase I and pharmacokinetics trial of ABI-007, a novel nanoparticle formulation of paclitaxel in patients with advanced nonhematologic malignancies. J Clin Oncol 23(31):7785-7793. https://doi.org/10.1200/ jco.2004.00.6148

29. Blum JL, Savin MA, Edelman G, Pippen JE, Robert NJ, Geister BV, Kirby RL, Clawson A, O'Shaughnessy JA (2007) Phase II study of weekly albumin-bound paclitaxel for patients with metastatic breast cancer heavily pretreated with taxanes. Clin Breast Cancer 7(11):850-856. https://doi.org/10.3816/CBC.2007.n.049

30. Fossella FV (2002) Docetaxel in second-line treatment of nonsmall-cell lung cancer. Clin Lung Cancer 3(Suppl 2):S23-S28

Publisher's Note Springer Nature remains neutral with regard to jurisdictional claims in published maps and institutional affiliations. 